\title{
Lider Üye Etkileşimi ve Çatışma Yönetim Stili İlişkisi: Bir Alan Araştırması
}

\author{
DOI: 10.26466/opus.529924 \\ * \\ Mehmet Güler* \\ *Dr. Öğr. Üyesi. İstanbul Üniversitesi, İktisat Fakültesi, İstanbul/Türkiye \\ E-Posta: mehmetguler86@gmail.com \\ ORCID:0000-0002-2956-7604
}

\section{Öz}

Bu çalışmanın amacı, örgütlerde yönetim kadrosunda yer alan lider vasıflı kişilerin astları üzerine belirledikleri davranışsal stillerin, ilişkilerine etkilerini ortaya koymaktadır. Lider-üye etkileşim kalitesi örgütün yönetim metodunda birincil etken olarak görülmektedir. Çatışmanın yönetimi çalışanlar arasındaki ilişkiyi pozitif ve negatif yönde doğrudan etkilemekteidir. Lider-üye etkileşiminin çatışma kültürü üzerindeki önemi tam olarka burada ortaya çıkmaktaıdır. Araştırma Türkiye' de turizm sektöründe çalışan iş görenleri kapsamaktadır. Çalışma, lider-üye arasındaki ilişkide hangi çatışma yönetimi stilinin daha sıklıkla tercih edildiğini tespit etmektir. Bu sebeple turizm sektörü bünyesinde 138 çalışandan anket yaparak veriler elde edilmiştir. Yapılan anket sonuçlarına göre; lider-üye etkileşimi yüksek bulunarak, turizm sektöründeki çalışanların çoğunlukla bütünleştirme en az kaçınma çatışma yönetim stilini seçtiği tespit edilmiştir. Bu anlamda lider üye ilişkilerinde bütünleştiren, uyma-ödün verme, ve uzlaşma çatışma yönetim stilleri ile olumlu yönde ilişkileri olduğu belirlenmiştir. Kaçınma çatışma yönetim stili ile anlamlı bir ilişki bulunamamıştır. Diğer taraftan, lider-üye etkileşim sürecide ilgili işletmenin kurumsal olması, imajı ve toplumsal kültür kodlarının etkisi olduğu tespit edilmiştir.

Anahtar Kelimeler: Çatışma Yönetimi, Liderlik, Yönetim 


\title{
Relationship Between Leader Member Interaction and Conflict Management Style: A Field Research
}

\begin{abstract}
The aim of this study is to determine the effects of behavioral styles on the subordinates of leading people in management.Leader-member interaction quality is seen as the primary factor in the management method of the organization. Conflict management directly and positively affects the relationship between employees. The importance of leader-member interaction on the culture of conflict emerges precisely here. Research in Turkey covers employees who work in the tourism sector. The aim of this study is to determine which conflict management style is preferred more frequently in the relationship between leader and member. For this reason, data were obtained from 138 employees in the tourism sector. According to the survey results; It has been found that the employees in the tourism sector mostly choose integration and least avoidance conflict management style. In this sense, it is determined that they have positive relations with leader member relations integrating, compliance-compromise, and reconciliation conflict management styles. There was no significant relationship between avoidance conflict management style. On the other hand, it was determined that the corporate, corporate image and social culture codes had an impact on the leader-member interaction process.
\end{abstract}

Keywords: Conflict Management, Leadership, Management 


\section{Giriş}

Küreselleşme, örgütlerin varlıklarını sürdürebilmeleri ya da rakiplerinden daha yüksek kar elde edebilmeleri için rekabet üstünlüğü sağlamasını zorunlu kılmaktadır. Ancak teknolojinin hızla gelişmesi ile artan rekabet ortamından avantaj elde etme imkanı gitgide azalmaktadır. Bu noktada örgütler, rekabet üstünlügü sağlamaları için temel sermayesi olan insan unsurunu gündeme getirmektedir.

Güçlü ve gerçek bir dinamiğe sahip olan örgütlerde çalışan verimliliğini artırmak önem arz etmektedir. Bunun devamında çalışanın birey ve grup olarak uyumu, tavır ve hareketlerini daha olumlu bir çizelgede ilerlemesini sağlayacak iç ve diş etkenler sorgulanmaktadır. İncelenen bu etkenlerden bir tanesi de liderlik sürecidir. Yapılan incelemeler bu sürecin tek başına akmadığını hem liderin hem takipçilerin aktif rol aldığını ortaya koymaktadır. Liderle takipçisi arasındaki bağ takipçiye göre ya da lidere göre farklılık göstereceği gibi şiddeti de aynı doğrultuda olmayacaktır.

Lider ve takipçisi arasındaki bu göreceli bağ; içtenlik, güven, sevgi ve saygı gibi unsurlardan fazlasıyla etkilenmektedir. Bu etkenlerin artış gösterdiği durumlarda bireylerin örgüte bağlllık hislerini yukarıya çıkarmaktadır. Bu kapsamda, lider ve takipçisi arasındaki bağ ne kadar nitelikli ise bireylerin motivasyonları ve verimlilikleri o kadar yukardadır.

Lider-üye arasındaki bağın niteliği üzerinde etkili olabilecek etkenlerden biri liderin üyeleri üzerinde uyguladığı çatışma yönetim stilidir. İnsanın var olduğu her alanda yaşanma ihtimali olan çatışmanın iyi yönetilmediği takdirde olumsuz ve yıkıcı sonuçları olduğu gözlemlenmektedir. Bu nedenledir ki yönetici vasfındaki kişilerin çatışmadan fayda sağlanması görüşüne sahip olmaları gerekmektedir. Çatışmaların olumlu sonuçlanması için de bu görüşe sahip olan yöneticinin süreci doğru yönetmesiyle mümkün olmaktadır. Lider üye ilişkisinin niteliği artırılmak istenen bir durum olduğu belirtilmektedir. Bu durum ise çatışmaların doğru yönetilmesinin bir sonucu olarak görülmektedir.

Bu bağlamda planlanan çalışmada; lider-üye arasındaki bağın kalitesinin artırılması doğru çatışma yönetim stratejisi seçilmesiyle mümkün olacağı öngörülmüş ve bu iki değişken arasındaki bağ incelenmeye çalışılmiştır. 


\section{Liderlik Ve Lider Üye Etkileşimi}

\section{Liderlik Kavramına Genel Bir Bakış}

Lider; etrafındakileri etkileyebilen, ilham veren ve doğuştan üstün özellikler taşıyan kişilerdir. Bu tanım, dikkate alınarak değerlendirildiğinde liderlik, bir kurala ya da baskıya yer vermeden bir iş veya görevin ya da varılmak istenen noktanın gerçekleşmesinde etkili olan kişilerdir. Bu ortak amaç ve hedefler için bir araya gelen bir çoğunluk var ise orada bir liderin varlığından söz edilebilir.

Liderlik olgusu çoğu bilim dalının irdelediği bir kavram olmuştur. Bu yüzden ortak bir tanımlamaya sığdırmak mümkün olmayacaktır. Farklı alanların konusu olduğu için farklı tanımlamaların ve ortak bir tanımın olmaması gayet doğaldır (Şişman, 2002, s.1).

Liderlik, yalnızca bir statüden doğmaz; liderlikte fark, insanları yönetme ve etkileme gücündedir (Dönmezer, 1999, s.272). Liderlik, insanların yaptıkları planları ve aldıkları kararlarını gerçekleştirmelerini sağlama sanatı olarak da tanımlanır (Ergun ve Polatoğlu, 1988, s.166-169).

Bu güne kadar liderlik üzerine birçok tanım yapılmıştır. En anlaşılır ve kolay tarifiyle lider, ortak bir hedef sunan ve bu hedef doğrultusunda kitleler yaratan, yol gösteren kişidir.

Örgütler açısından liderin rolü; iş görenleri örgüt hedefleri doğrultusunda verimliliklerini en üst noktaya çıkararak iş görme edimini yerine getirmesini sağlayandır. Nitelikli bir lider elindeki mevcut kaynakları örgüt amacı doğrultusunda en etkin kullanandır. Örgüt için en önemli kaynak insan unsurudur. Bu nedenle lider örgüt amaçları ile insan unsurunun iş doyumunu ayn doğrultuda ilerletmelidir. Değişen ve farklılaşan dünyaya uyum sağlayacak olan lider aynı uyumu örgüt için ve üyeleri içinde uygulamalıdır.

\section{Lider - Üye Etkileşimi Kavramı}

Uzun yıllardan beri örgütlerin ve grupların hedeflerine ulaşmada ki en temel etken liderlik süreci olarak görülmüştür. Liderlik sürecinde sadece tek taraflı etkiden bahsedilmemektedir. Liderin etkisi altına giren üyeler olarak söz ettiğimiz kitlenin de süreç içinde aktif rolü olması ve çift taraflı 
bir etkileşim, değişim süreci olduğunu söyleyebiliriz. Bu etkileşim lider ve üye arasında ki karşılıklı güven, sevgi, saygı ya da üyenin bazı davranışsal özelliklerine bağlı olarak farklılık göstereceğini ve şiddetinin de her üye ve lider için aynı olamayacağını belirtilmelidir. 1970'li yılların ortalarına kadar olan dönemde mevcut liderlik araştırmaları, liderin astlarını bir bütün olarak gördügü ve liderin tüm astlarına eşit seviyede "ortalama" bir liderlik davranışı sergilediğini varsaymaktaydı (Danserau, 1975, s.47). Klasik görüş olarak adlandırılabilecek bu görüşe göre lider tüm astlarına aynı şekilde davranır, fakat astlar farklı şekilde algıladıkları için mevcut farklılıklar görülürdü (Danserau, 1995, s.480).

Modern liderlik kuramlarından biri olan lider-üye etkileşimi, etkili liderlik araştırmalarının omurgasını oluşturmaktadır (Tabak, 2005). Çağımızda liderin farklı faktörlere göre davranışlarının değişkenlik göstereceği ve üyelere yaklaşımının da farklı olacağı anlaşılmaktadır. Bu durumda dikey ikili bağlantı modeli kapsamında değerlendirilen lider-izleyici ilişkileri, günlük yaşantıda gerçekçi bir bakış açısı oluşturmaktadır (Zel, 2006, s.164-165).

Lider üye etkileşim süreci bazı örgütsel neticeler üzerinde etkili olduğuna dair çalışmalar yapılmıştır. Yapılan bu çalışmalar lider üye etkileşim prototipinin, başka liderlik kuramlarının çok üstünde olduğunu göstermektedir. 1980'li yıllardan bu yana lider üye modeline ulaşılana kadar pek çok kez aynı konu üzerine farklı boyutları incelenmiştir.

Bu çalışmaların en önemli katkısı lider üye etkileşimde ki niteliğin üyenin davranışsal boyutuna göre farklılık göstereceğidir. Liderlikle ilgili önceki araştırmalara göz gezdirdiğimizde standart bir liderin üyelerine aynı şiddette davrandığı görülmektedir.

Liderin üyeleri ile olan etkileşiminin kalitesini farklı düzeylerde yani düşükten yükseğe farklı şiddette oluşturması lider üye etkileşiminin farklılaşması olarak tanımlanabilir. Bu farklılaşma üyeler içinde iki küme oluşturur. Bunlar grup içindekiler ve grup dişındakiler olarak açıklanabilir. Grup içindekiler olarak belirttiğimiz lider ile aralarında güven sevgi ve saygı olduğunu bunun sonucunda diğer gruba göre daha kaliteli bir etkileşimin var olduğu söylenebilir. Grup dışındakiler olarak nitelendirdiğimiz üyelerin ise lideriyle aralarında daha çok resmiyetten ileri gelen bir saygı vardır. Bu durum daha çok olumsuz ve etkileşim kalitesinin düşük olduğunu gösterir. 
Bu çalışmalara bakıldığında üstleriyle daha kaliteli ilişkilere sahip olan astlar örgütsel açıdan bakıldığında daha iyi performans gösterip verimliliklerinin arttığı görülmüştür. Bu iyi ilişkiler yöneticinin astına daha anlayış göstermesine sebep olurken iş yapışında esnek alan sağlayarak astı serbest bırakmaktadır. Böylelikle ast daha fazla sorumluluk alıp işine olan bağlılı̆̆ını arttırmaktadır. Nitelikli lider üye ilişkisine sahip üyeler; grup dışı olarak adlandırdığımız üyelerden daha fazla takdir edildiği daha çok mesuliyet verilmiştir.

\section{Lider - Üye Etkileşim Kalitesini Etkileyen Faktörler}

Lider üye etkileşim süreci sosyal ve psikolojik bir süreç olarak ilerlerken liderin üyesi ile kuracağ 1 ilişkinin kalitesi her üye için farklı olacaktır. Bu farklılığın temelinde yatan bazı değişkenler bulunmaktadır. Bunlar liderin gücü, örgütsel stratejiler, bireysel ve demografik özellikler olarak ele alınmaktadır.

$\checkmark$ Liderin gücü; bu başlık altında yapılan çalışmalarda liderin bu güce nasıl sahip olduğu, bu güç türlerinin ne olduğu, bu farklı güç türlerini üyelere nasıl ve hangi şiddette uyguladığı araştırmalara konu olmuştur. Güç; liderin üyeler üzerinde yapmak istemedikleri iş ve işlemleri gerçekleştirebilme, üyeleri tesir altında bırakarak davranışlarını şekillendirme kapasitesidir. Buradan yola çıkarak liderin ihtiyaç halinde üyeleri üzerinde gücünden yararlanarak etkileme sürecine girdiği anlaşılmaktadır. Liderin amirleri ile iyi ilişkiler kurduğu noktada gücünden bahsedilir. Astlarına mevcut kaynakları sağlayabilmesi için güce sahip bir lider olması gerekmektedir. Örgüt içinde liderin 5 temel güç kaynakları bulunmaktadır. Örgütün yöneticiye imkan sağladığı yasal güç, zorlayıc güç ve ödül gücü yer alırken; yöneticinin bireysel olarak karizmatik gücü ve uzmanlık gücü vardır. Güç kaynakları lider ve üye arasındaki etkileşim sürecinin gelişimini sağlamaktadır (Fındıklı, 2012, s.100).

$\checkmark$ Örgütsel stratejiler; lider astlarının davranış biçimlerini değerlendirirken bu davranış karşılığında göstereceği tavır örgüt stratejilerine uygun olmaktadır. Buradan yola çıkarak liderin örgüt stratejilerinden etkilendiğini söyleyebiliriz (Fındıklı, 2012, s.101). 
$\checkmark$ Bireysel ve demografik özellikler; lider üye etkileşimi kalitesinde liderin benzerlikten ya da kişisel bazı bir takım özelliklerden etkilenebilmektedir. Şayet lider ve ast aynı cins bireyler değillerse etkileşimin kalitesi düşebilmektedir. Örgütlerde çoğunlukla orta ve üst kademedeki yöneticileri erkeklerin oluşturduğu göz önüne alınırsa kadınlar erkeklere oranla ast üst ilişkisinde daha dezavantajlı konumda olacaktır. Demografik benzer özellikler taşıyan taraflarda ise kültürel olarak da birbirlerini daha çok koruma kollama içgüdüsüyle hareket edecektir. Lideri ya da astın eksik noktalarında daha toleranslı davranacak ve ilişkinin kalitesinin etkilenmemesi açısından devamlılığını sağlayacaktır (Findiklı, 2012, s.102).

Bu faktörlerden ayrı liderin zaman kaygısı olacaktır. Bu zaman kaygısı lider üye arasındaki etkileşim kalitesinde etkili olmaktadır. Zamanı kısıtlı bir lider için örgüt hedefleri doğrultusunda astları arasında alt bir küme oluşturacak önemli saydığı görevlerin birçoğunu bu şekilde tamamlayacaktır. Bu bağlamda grup içi astlarıyla kaliteli etkileşim elde edecek ve çoğunlukla daha iyi anlaşacaktır. Grup içi astlar kilit sayılabilecek görevleri üstlendiğinden bu iş ve işlemlerde oluşabilecek ya da var olan sorun ve problemleri liderine ileterek çözüm sağlayacağından taraflar arasındaki bağ daha da güçlenecektir. Grup dışı kalan astlar ise lideriyle arasındaki bağ ve uyum daha düşük seviyede seyredecektir.

Etkileşimin kalitesinde engel teşkil edebilen bazı örgüt politikaları ya da kolektif hareketler (sendikalar) olacaktır. Örneğin bazı örgütlerde sendikaların varlığı çalışanlara eşit tutum gösterilmesinde rol oynayabilir. Böyle bir durumda liderin tüm astlarına eşit tavır sergilemesi gerekecektir. Oluşabilecek diğer bir engel taraflar arasında herhangi bir sebepten dolayı güven duygusu gelişmemiş olabilir ve buda etkileşim kalitesinde negatif yönde etkileyecektir. Astlarda birbirinden etkilenerek etkileşim kalitesinde negatif etkiye yol açabilirler. Örneğin daha özverili çalışmaya meyilli bir astın diğer astlardan etkilenerek bu tavırdan kaçnabilir. Lider de her zaman aynı çabada olmayabilir. Etkileşimin kalitesi uğruna zamanını ya da mental olarak kendisini tüketmek istemeyebilir.

Yöneticiler astlarına her durumda ve her zamanda aynı yaklaşamayabilir. Bu durumunda astlar iki gruba ayrılmaktadır. Yöneticisinden beklediği ilgiyi göremeyen grup dışı astlar işbirliğinden uzak hatta düşmanca 
tavırlar sergileyebilmektedir. Sonuçta ikili gruptaki etkileşim farklılığı çatışma potansiyelini artırabilir.

Liderin astlarına karşı tavrı negatif yönde farklılaştıkça astların örgüte olan bağlılığı azalacak ve işte ayrılmalara neden olacaktır. Liderin buradaki görevi grup dışı astlarına da grup içi astına davrandığı gibi tavır sergilemesidir. Liderin, kendisine destek ve kaynak sağladığını hisseden astın lidere daha olumlu yaklaştığı ve yardımcı olduğu, örgüte olan bağlıl1ğında ise artış göstermektedir. Temelde taraflar arasındaki etkileşim kalitesi astların adalet ve eşitlik kaygısından yola çıkmaktadır. Liderin bunu öngörüp ona göre etkileşimini belirlemesi gerekir. Adalet kaygısı güden astın yöneticisine, takım arkadaşlarına, örgüte olan tüm güven duygusunu yitirmesine, örgüte yabancılaşıp yıkıcı bir çatışma içine girmesine neden olur. Bu süreç işten ayrılmalara kadar gideceği için örgüt açısından devir oranının artmasıyla maliyeti olumsuz etkileyecektir (Bucak, 2010, s.18).

Etkileşim kalitesi düşük lider üye ilişkisinde liderin astına durumsal liderlik modeli ile yaklaşması yani aynı olmayan durumlarda astına uygun bir iş tasarlaması üyenin örgüte olan bağlılığını artıracaktır.

\section{Lider - Üye Etkileşimin Örgütsel Sonuçları}

Scandura ve arkadaşlarına göre (1986) lider üye etkileşimi, bireysel özneler ve ilişkinin öznelinde oluştuğu, iki yönlü de tarafların aktif olduğu, oluşacak ya da oluşma ihtimali olan sonuçların iki tarafında etkilendiği bir modeldir. Buradan yola çıkarak lider üye etkileşimi, etkileşim sürecinde olan bireyler birbirine feyz vererek ve ortak sonuçlara da birlikte varırlar. Lider üye etkileşimin niteliği bireysel, grupsal ve örgütsel olarak ortaya çıkacak sonuçları tayin etmektedir (Gerstner ve Day, 1997).

Lider üye etkileşim modelinde ikili ilişkinin iki ayrı noktada ayrıldığı üzerinde durulmaktadır. Grup içi (iyi), grup dışı (kötü) olarak iki başlık belirlenmiştir. Ancak bu durum yapılan çalışmalar neticesinde lider üye etkileşim modelinin algı noktasını değiştirmiştir. Lider üye etkileşim modelinin liderden ve astından örgütsel açıdan nasıl olumlu sonuçlar elde edilebilir noktasını önemli hale getirmiştir. 
Yapılan çalışmalarda lider üye arasında kaliteli bir ilişkide bulunan üyenin iş performansında örgüte olan bağlllığında artışlar gözlemlenmektedir. Aynı zamanda etkileşim kalitesi yükseldikçe aynı oranda örgüt içinde ki çatışma potansiyeli azalmaktadır. Bunların yanı sıra kaliteli ilişki için liderin üyesine yetkisinin bir kısmını devretmesi sorumluluk ve insiyatif hakkı tanıması ve kariyer çizelgesi oluşturması ilişkiyi pozitif yönde etkilemektedir.

Literatürde birçok kaynakta bahsedilen lider ve üyenin takındığı tavrın en önemli belirleyicisi, örgüt içinde üyenin performans göstergesi ve bu performansın nasıl gelişme kaydettiğidir. Liderler üyelerine sağladıkları maddi ve manevi kaynaklar için üyenin çalışma hayatındaki performansına bakarlar. Elde edilen kaynak karşısında üye örgüte katma değeri yüksek verimlilik sağlarlar. Bunun karşllı̆̆nda liderin üyeye olan güven ve bağ duygusu gelişecektir. Artan güven duygusu üyenin daha fazla sorumluluk ve yetki almasıyla sonuçlanacaktır.

\section{Çatışma Ve Çatışma Yönetim Stili}

\section{Çatışma Kavramı ve Türleri}

Çatışma, insanın oluşturduğu grupların, örgütlerin doğasında var olan evrensel bir kavram olarak her alanda karşımıza çıkmaktadır. Yaşanan çatışmaların örgüt içinde var olması bazı sonuçlara yer vermektedir. Çatışma klasik yönetimden bu yana örgüt açısından negatif yönde olduğu ve tamamen yok edilmesi gereken bir durum olarak algilanırken modern zamanda çatışmanın her zaman yıkıcı olamayacağı yapıcı sonuçlar elde edilebileceği bunun için doğru bir strateji ile yönetilmesi gerektiği savunulur. Bu farklı görüşlerin gerçekliği çatışmanın hangi taraflar arasında hangi nedenle ve bu tarafların bireysel özellikleriyle, tecrübelerine bağlı olarak yapıcı yada yıkıcı sonuçlar elde edilebileceği değişkenlik göstermektedir (Demiröz, 2015, s.18-20).

Örgüt açısından bireylerin geçmişte yaşadıkları durumlar göz önüne alındığında hepsinin farklı durumlara farklı tepkiler vermesi tecrübeleri kişisel bazı özellikleri ya da çıkar ilişkilerini göz ardı edilmeden potansiyel bir çatışmanın varlığı inkar edilemez. Çatışmanın eksikliklerden ya da 
farklılıklardan doğduğunu yani örgüt içinde sınırlı kaynağa sahip olunması, bireyler arasında güç ve statü kaygısı kişileri hem birbiri ile hem kendileriyle çatışma yaşamasına neden olacaktır. Görüş ayrılığından, kaynak eksikliğinden oluşabilecek çatışma gruplar arasında nefret söylemlerine neden olacağından pasif haldeki sürecin saldırgan tavırlara dönüşmesiyle aktif bir süreç içine girecektir. Bireylerin elde etmek istedikleri statü ve güç sürtüşmeler yaşamalarına ve bir gerilim hattı oluşmasına dayanak oluşturacaktır.

Negatif doğrultuda hissedilen çatışmanın her zaman olamaz. Bazı durumlarda olumlu noktada etkileri de olacaktır. Çoğunlukla örgüt üzerinde çıkar kayıplarına, saldırganca duyguları ateşleyeceğine, güven ve itibar kaybı yaşanacağına dayanak olarak görülse de, her durum için geçerli değildir. Bireylerin beklentileri ve amaçlarının çatışmasında, örgüt içinde görev bozukluğu olarak görülür ve olumlu olmayan sonuçlar yaşanacağ 1 düşünülür. Aslında çatışmanın insanın var olduğu her alanda var olması gibi, örgüt içinde de yaşanması olağan ve sıradan bir durum olduğu kabullenilmelidir. Farklılıklardan doğduğunu belirttiğimiz çatışmanın zaten örgüt içinde olmaması her şeyin stabil herhangi bir değişikliğe yaratıcılığa ya da yeniliğe yer vermemiş bir örgüt demektir (Kirişçi, 2010, s.40-41).

Çatışma sadece stabil örgüt davranışına karşı çıkmamaktadır. Bunun yanı sıra örgüt politikalarına kadar değişlik gerektiren bir geri bildirim aracı olarak görülmüştür. Özet olarak çatışmayı sınırlı kaynakların, bireylerin hedef ve çıar farklılıklarından kaynaklanan gerilim durumudur diye ifade edilebilir.

Literatürde genel hatlarıyla çatışmanın türleri olarak alt basamaktan üst basamağa kadar üç aşama belirlenmiştir. Bunlardan kaynakların s1nırlı hale gelmesi ile bireyler arasında kaynakları elde etme mücadelesine gerilime neden olan pazarlık modeli çatışmasıdır. İşgören ve iş veren arasındaki ilişkiler kurmay eleman olarak adlandırılan (müfettiş, danışman, uzman) elemanların bütçe oluşturma süreçlerinde yaşadıkları potansiyel çatışmayı da pazarlık modeline dahil edilmektedir. Dikey hiyerarşi olarak belirtebileceğimiz astın üstüyle üstün astıyla çatışması ise bürokratik model olarak tariflendirilir. Üstün astına uyguladığı, hal ve tavırlarını kontrol etme durumu, örgütün gidişatı üzerine yapılan çalışmalar gerginliğe neden olacağından buradaki potansiyel varlığını koruyacaktır. Örgüt 
içinde belirli bir iş için aynı statü ancak farklı birimlerdeki iş görenlerin ilişkilerinde yaşadıkları gerilim sistem yani idareci modeli ile açıklanmıştir.

Örgüt içinde yaşanan çatışmaların tarafları göz önüne alarak ayrıştırdığımızda burada yaşanan çatışmaların bireyin kendi içinde içsel çatışması, bireyler arasında yaşanan çatışma, bireyin grupla birlikte karşılıklı yaşadığı çatışmaya da örgütler arası yaşanan çatışma olarak ayrıştırılmaktadır. Bunların dışında çatışmanın şiddetine ve meydana gelmesine göre gruplandırılabilir. Bu çatışmalar potansiyel, algılanan, hissedilen ve açık çatışma olarak gruplandırılmaktadır (Bayık, 2016, s.9-12).

Konusuna göre çatışmalar da kendi arasında ayrım göstermiştir. Bunlar görev, ilişki ve süreç çatışmalarıdır.

\section{Çatışmanın Süreci, Nedenleri ve Sonuçları}

\section{1. Çatışmanın Süreci}

En az iki ya da daha fazla bireyler arasında olgunlaşan çatışmalar aşamalar halinde incelenmektedir. Her aşama bir sonraki aşamanın sarsıcı şekilde tetikleyicisi halini almaktadır. Bu noktada bireylerin yaşadığı ortamın şartları, algılama düzeyleri, tecrübelerinin getirisi duyguları çatışmaları hangi aşamada ve nereye doğru ilerlediğini belirlemektedir (Karcı-ğullar ve Alioğulları, 2012, s.4).

Sonu bilinebilir olan çatışma süreci bazı durumlarda şiddeti artarak düşmanca tutumla birlikte açık bir saldırıya dönüşebildiği gibi bazı durumlarda da sorunların tamamen ortadan kaldırılmasında etken olabilir.

Çatışmalar aşamalarına göre gizli çatışmalar, algılanan, hissedilen, açık çatışmalar ve çatışma sonrası gibi basamaklarla var olmaktadır. Sınırlı kaynakların olduğu ve örgütlerin ayrıldığı alt departmanların hedeflerinin farklılığından kaynaklı gizli çatışmalar yaşanmaktadır. Karşılıklı ortak bir karara varılamadığı müddetçe gizli çatışmalar devam edecek ve farklı gizli çatışmalarda ortaya çıkacaktır. Örgütlerde bireyler arasında yaşanan rol çatışmaları gizli çatışma için en iyi örnek olacaktır.

Çatışmaların yaşanabilmesinde birçok farklı etken rol oynayabilmektedir. Şayet potansiyel çatışmaya taraf olmuş bireyler arasında hedef farklılıkları gibi ya da, algılama farklılıkları, inandıkları ve değer verdikleri 
kavramlar hakkında çatışma yaşamaktadırlar. Bazı durumlarda taraflardan bir tanesi çatışmanın varlığından bile habersizken karşı taraf için yaşanan çatışma düşmanca ve saldırganca tutum sergileyecek hale gelebilmektedir. Bunun beraberinde yaşanan gizli çatışmanın oluşum nedeni olarak daha önce yaşanmış ve düzeyleri değişkenlik gösteren çatışmalar olabilir. Tabi bunun yanında gizli çatışmanın varlığından söz edebilmek için çevresel yani dışsal faktörleri hiçe saymamak gerekmektedir (Altay, 2011, s.38-41).

Yaşanan çatışmaların bitiminde dışarıya bazı olumlu veya olumsuz sonuçlar yansımaktadır. Bireyler arasında yaşanan çatışmalar sözel halde ya da fiziksel anlamda saldırgan noktaya gelmesiyle açık çatışmanın oluştuğu gözlemlenebilmektedir. Burada önemli olan taraflardan en az birinin saldırgan tutumu fark etmesi olduğu kadar bilinçli ve planlı şekilde bu tavrı sergilemesi gerekmektedir.

Bireylerin birbirine karşı davranış şekilleriyle algılanan veya hissedilen çatışmalar ortaya çıkmaktadır. Çatışma esnasında bireylerde ki duygu düzeyleri normal bir döneme nazaran daha yüksek olacağından iletişimlerinde bazı aksaklıkların meydana geleceği açıktır. Çatışmalarda süreci ilerleten durum aslında karşılıklı bireylerin yaşanan çatışmayı sona erdirme ya da erdirmeme isteğiyle doğrudan bağlantılıdır. Bu noktada taraflardan biri çatışmadan kaçmaya istekli olabilirken, diğer taraf kendisini müdafaa etme eğilimin olacaktır.

\section{2. Çatışmanın Nedenleri}

Örgüt içinde çatışmanın oluşması için sayısız neden sayılabilmektedir. Burada değinilmesi gereken en önemli yer çatışma var ise neden oluştu ve çözerken nasıl bir yol haritası izlenmelidir. Çatışmayı anlamak, yönetmek ve çözebilmek örgütün büyük ya da ufak olması fark etmeksizin önemli aşamalardır.

Çatışmanın neden var olduğu ile ilgili detaylar birçok çalışmada yer bulmuştur. Bir çatışmanın oluşması için pek çok neden var olabilir. Örgüt içinde bireyler ya da gruplar arası güç paylaşımı, bireyler örgüt içinde sahip olmak istedikleri kaynakların sınırlı olması, gruplar arasında amaç farklılığı, bireylerin algılama düzeyleri ve farklılıkları gibi daha pek çok 
kez uzatılabilir nedenler çatışmalar için uygun ortamı hazırlamaktadır (Altay, 2011, s.42).

Örgüt içinde kişiler ve kişilerin oluşturduğu grupların hedefleri birbiri ile aynı paralelde olmaması, geçmişte yaşayıp bugüne getirdikleri tecrübe ve inançlarının zıt olması, örgüt içinde her türlü kaynakların sınırlı sayıda var olması, örgütün içinde olan kuralların dengesiz ve kişiden kişiye farklılık göstermesi ya da iletişimden kaynaklanan algılama hataları gibi nedenler çatışmanın oluşması için yeterli seviyede olmaktadır.

Tüm bu nedenlerin yanında çatışma kendiliğinden oluşan bir durum olmadığı gibi şiddetinin azalıp artması da kendiliğinden olmamaktadır. Bu noktada aslında çatışmanın bireyler üzerinde yönlendirici bir etkisini düşünmek yerine, bireylerin çatışmayı doğru yönetmesiyle yapıcı bir adım kaydedilirken tam tersi bir durumda yıkıcı sonuçlar ortaya çıkabilmektedir.

\section{3. Çatışmanın Sonuçlan}

Çatışma üzerine belirli bir aşamaya geldiğinde yaratıcılık, devamlılık bakımından bazı olumlu ya da olumsuz sonuçlar görmek mümkün olmaktadır. Örgüt içinde gerçekleşen çatışmanın fonksiyonel olan ve fonksiyonel olamayan etkileri mevcuttur. Yaşanan çatışmaların birçoğu bireylerin hedef uyuşmazlıklarından kaynaklanmaktadır. Bu sebeple taraflardan birinin hedefe ulaşması diğer tarafın ulaşmamasıyla sonuçlanacağından çatışmayı doğurduğunu bilinmektedir. Örgüt içinde yaşanan gerginliklerin çözümlenmeyip karmaşık bir çatışma halini alması grup içinde motivasyon düşüklügüne sebep olacağı gibi, gergin ortamdan uzak durmak isteyen bireyler oluşturacak ve işten ayrılma oranını artıracaktır. Örgüt içinde yaşanan çatışmaların birçoğu yönetime katılanların kararlarında gizli bir etken gizli bir gündem yaratmaktadır. Yaşanan gerginliklerin özüne bakıldığında çözülmemiş geçmişten bugüne ortaya dökülmemiş gizli bir gündem olmuş ve sonradan ortaya çıkmasıyla her kararı etkileyen bir boyuta ulaşmıştır. Daha önce çatışmanın maliyete olumsuz etkileri olduğu belirtilmiştir. Ancak sadece olumsuz etkilerden bahsetmek çatışmanın varlığına ters etki yaratacaktır. Maliyeti olumlu yönde etkileyen sonuçları yeniliği, yaratıcılığı artırmasıyla örgüt içinde yeni fikirler oluşmasında se- 
bep gösterilmektedir. Grup içinde çatışma ile artan rekabet bireylerin verimliliğini yukarıya çekecektir. Bu bağlamda çatışmanın denge noktasına getirilmesiyle olumlu sonuçlarıyla karşılaşmak mümkün olmaktadır (Nebioğlu, 2011, s.29-37).

\section{Çatışma Yönetim Stili ve En Uygun Stilin Seçimi}

Örgüt içinde çatışmayı yönetecek kişi grubun lideridir. Aynı zamanda liderin çatışmayı doğru seviyede tutması beklenmektedir. Liderin zaten çatışmanın örgüt bakından son derece önemli olduğunun farkındadır. Liderlerin örgüt sorunları arasında en çok vaktini alan durumlar çatışmanın yönetimi seviyesi ve çözümleri gibi konulardır. Çatışmanın çözümü için başvuran stratejiler her durum için farklı şekillendiği kadar liderin nasıl bir yönetici olduğu ile ilgilidir. Çatışma stratejileri açısından tek stilin iyi olduğunu söylemek mümkün değildir. Liderlik stili günün durumuna ve koşullarına göre değişiklik göstereceğinden çatışma stratejileri içinde aynı durum geçerlidir. Bunların yanı sıra bazı liderlerin kişilik ve karakter bakımından kendine daha yakın hissettiği bir çatışma yönetim stratejisini her durumda uygulamak için israrcı davranabilmektedir. Belirtilmelidir ki çatışma yönetim stillerini tamamen birbirinden bağımsız düşünmek yerine bazı çatışma kalıpları üzerinde birden fazla stilinin birleşimi çözüm sağlayabilmektedir. Çatışmalara birçok durumun sebep olacağı doğru olmakla birlikte yönetiminde esas değinilmesi gereken nokta sonuçlar dikkate alınmaktadır. Çatışmanın çözümünde taraflar arasındaki tutumun önceliklerinde kendi isteklerini düşünerek çözüme gitmeleridir. Ancak bu şekilde gerilimin şiddeti düşürülmezse karşılıklı özverilerde bulunarak çözüm bulunmalıdır (Altay, 2011, s.48-57).

Çatışma yönetim stillerinin birçok araştırmacı tarafından bazı belli davranış kalıplarına tanımlamalar yapılmakla birlikte isimlerinde değişkenlik gösterse bile sonuca gitme yönteminde benzerlik göstermektedir. Literatürde bireylerarası çatışma yönetim stili olarak bütünleştirme, uyma-ödün verme, hükmetme, kaçınma ve uzlaşma davranış tarzları benimsenmiştir.

$\checkmark$ Bütünleştirme; tarafları anlaşmaya vardırmak için karşılık beklenti ve ihtiyaçları bütünleştirir. Çatışan tarafları yüz yüze getire- 
rek beklentilerini olduğu gibi ortaya koymalarını sağlar. Tarafların haklı veya haksız oldukları önemsenmez buradaki hedef fikir ayrılıklarını ortaya koyarak çözüm bulmaya çalışılır. Bütünleştirme çatışma yönetim stratejisinin doğru işlemesi için tartışmanın sağlıklı gerçekleşeceği iyi niyet ve güven ortamı sağlanmalıdır. Şayet böyle bir ortam yoksa çatışma yıkıcı bir durumla sonuçlanabilir (Kirişçi, 2010, s.50).

$\checkmark$ Uyma- Ödün Verme; taraflardan birinin kendi istek ve beklentilerinden karşı tarafla anlaşma sağlanabilmesi bakımından feragat etme durumudur. Taraflardan ödün veren diğerine nazaran daha naif ve zayıf olduğu düşünülmektedir. Ödün veren taraf için beklenti ve isteklerin önemsiz olduğu düşündürülerek anlaşmaya varmaya çalışırlar (Kirişçi, 2010, s.51).

$\checkmark$ Hükmetme; taraflardan birinin çatışma sorununu çözebilmek adına güç ve otoritesini uygulayıp diğer tarafın durumu kabullenmek zorunda bırakıp sorunun ortadan kaldırıldığı modeldir. Bu modelde önemsenmesi gereken nokta otoritenin ve gücün olmadığı tarafın uygulanan baskı karşılığında istek, moral ve motivasyonun azalacağı öngörülmelidir. Bu nedenle hükmetme modeli gerçekten elzem olduğu durumlarda başvurulması gereken bir çatışma yönetme stratejisi olmaktadır (Kirişçi, 2010, s.52).

$\checkmark$ Kaçınma; yöntem adından da anlaşılacağı üzere çatışmanın üzerine gidilmediği yok sayıldığı ve açık bir hale getirilmediği bir çatışma yönetim stilidir. Çoğunlukla eşit derece statüye sahip durumlarda ya da birbirine bağımlı pozisyonlarda yaşanan çatışmalarda bu yönteme başvurulabilir (Kirişçi, 2010, s.53).

$\checkmark$ Uzlaşma; tarafların istek ve beklentilerinden taviz vermesiyle oluşan çatışma yönetim stratejilerinden biridir. Sonuç alınamamış ve örgütün uzun süreli vaktini aldığı çatışmalarda bu yönteme başvurmak akıllıca olacaktır (Kirişçi, 2010,s. 54). 


\section{Lider-Üye Etkileşiminin Çatışma Yönetim Stili Üzerine Etkisi: Turizm Sektöründe Bir Araştırma}

\section{Araştırmanın Konusu ve Amacı}

\section{Araştırmanın Konusu}

Turizm sektöründe yapılan anket çalışmasının konusu, örgüt yöneticilerinin seçtikleri çatışma yönetim stilinin, lider- üye etkileşimi üstündeki etkileri incelemektir.

\section{Araştırmanın Amacı}

Daha öncede ayrıntılı bir biçimde yazdığımız gibi örgüt için çalışan verimliliğinin en üst seviyede olması önemlidir. Bunun için niteliği yüksek lider üye ilişkisi ve doğru çatışma yönetim stilinin seçilmesi önemlidir. Örgüt içinde hep var olan çatışmaların yönetiminde doğru yönetim stilini kullanmak lider üye ilişkisinin kalitesinde etkili olacağını belirtebiliriz. Örgüt başarısı için liderlik boyutunun iyi uygulanması gerekir. Bu bağlamda liderliğin yöneticiler tarafından iyi uygulandığı durumlarda ortam şartlarının iyi anlaşılmış olması gerekir ki ilişkide ki nitelik boyutu artırılabilsin. Bu bakımdan yapılan çalışmanın amacı için yöneticilerin uyguladıkları çatışma yönetim stillerinin lider üye ilişkisinin kalitesi üzerinde ki etkileri olumlu anlamda artırmak olacaktır.

\section{Araştırmanın Yöntemi ve Analizi}

Yapılan araştırmada yöntem olarak veri toplama aracı olan anket yöntemi uygulanmıştır. Yapılan anket sadece alt kademlerde yer alan 138 ayrı çalışana uygulanmıştır. Elde edilen sonuçlar SPSS programı ile veri oluşturulmuştur. Oluşturulan bu verilen frenkans analizi ve yüzde dağılımları tablo halinde sunularak sonuca gidilmiştir. Anket 3 bölümden oluşmakta olup birinci bölümde demografik soruların yer aldığı toplamda 6 sorudan oluşurken ikinci bölümde yine 6 soruda tamamlarken üçüncü bölümde 16 soru ile toplamda 28 soru ile anket tamamlanmıştır. Anketin geçerliliğini 
test etmek amacıyla alan uzmanlarına gösterilerek tartışılarak anket oluşturulmuş, ayrıca, 33 çalışana uygulanarak görüşleri alınmış anlayıp anlamadıkları kontrol edilerek düzeltmeler yapılmıştır. Güvenirliğini belirlemek için de Cronbach Alpha iç tutarlılık katsayısına bakılarak; Cronbach Alpha iç tutarlılık katsayısı 0.78 olarak bulunmuştur. Soruların çatışma yönetim stili yaklaşımlara göre dağılımı aşağıdaki gibidir.

$\checkmark$ Bütünleştirme: 1,3,12,13,16

$\checkmark$ Uyma- Ödün Verme: 2,8,10,14

$\checkmark$ Hükmetme: 6,7,11

$\checkmark$ Kaçınma: 4,15

$\checkmark$ Uzlaşma: 5,9

\section{Anket Sonuçları}

\subsection{Demografik Sonuçlar}

Yapılan anketin ilk bölümünde yer alan ve anket sorularını cevaplandıran çalışanların demografik özelliklerini belirleyebilmek amacıyla analiz sonuçları aşağıda verilmiştir.

\subsubsection{Araştırmaya Katılanların Yaş Yüzde Sonuçları}

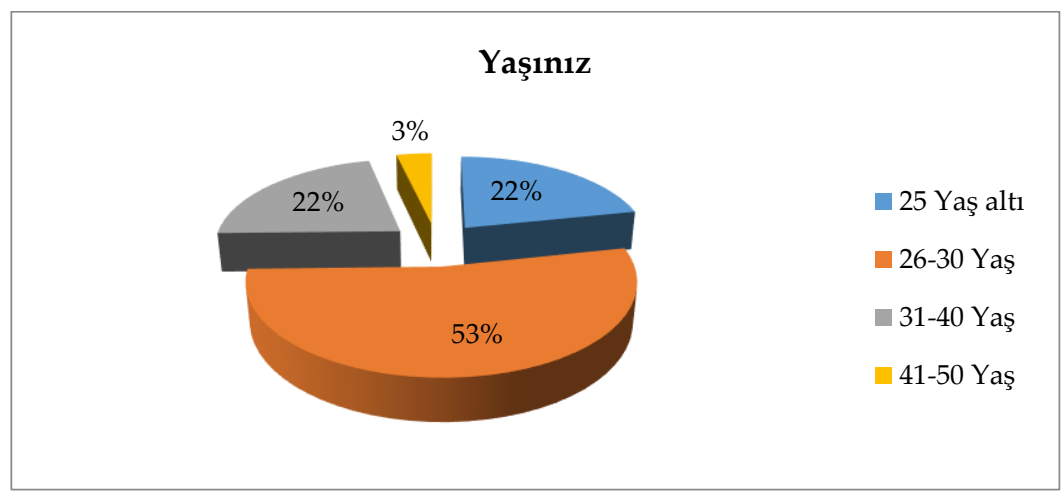

Araştırmaya katılan turizm çalışanlarının 30' u 25 yaş altı (\%22), 73' ü 2630 yaş aralığ 1 (\%53), 30’ u 31-40 yaş aralığı (\%22), 5' i 41-50 yaş aralığında$\operatorname{dir}(\% 3)$. 


\subsubsection{Araştırmaya Katılanların Cinsiyet Sonuçları}

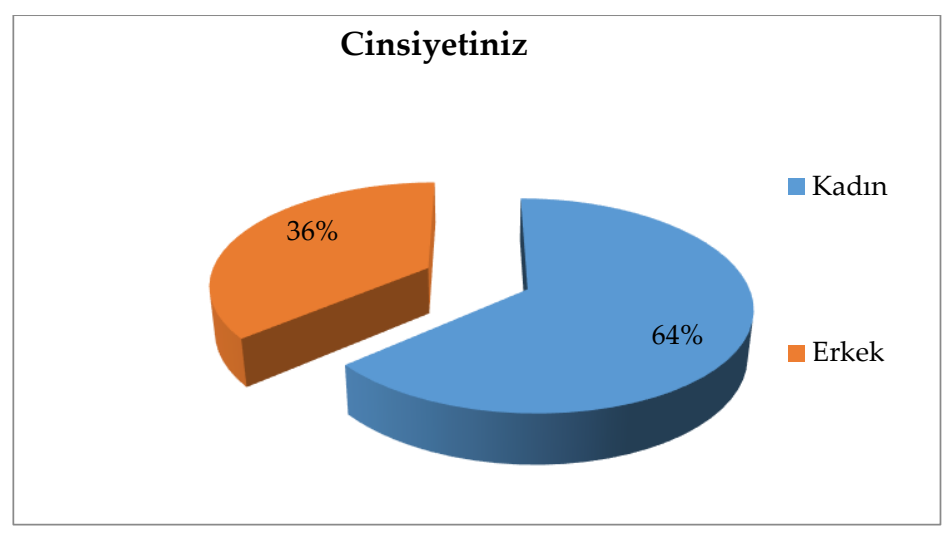

Araştırmaya katılan turizm çalışanlarının 88' i kadın (\%64), 50’ si erkek cinsiyetine sahiptir (\%36).

\subsubsection{Araştırmaya Katılanların Öğrenim Durumu Sonuçlarn}

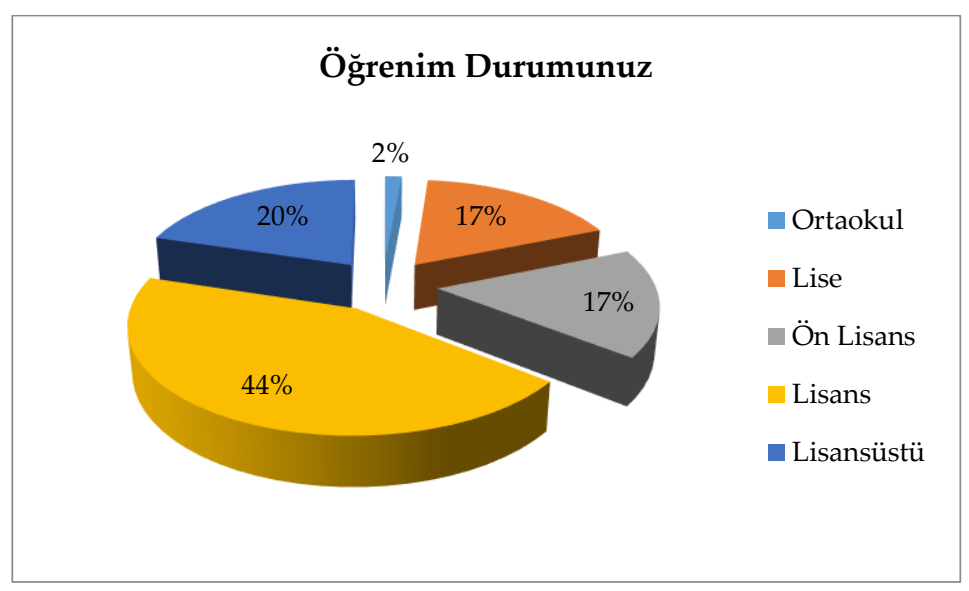


Araştırmaya katılan turizm çalışanlarının 2' si ortaokul (\%2), 24' ü lise (\%17), 23’ ü ön lisans (\%17), 61' i lisans (\%44), 28' i lisansüstü öğrenim durumuna sahiptir (\%20).

\subsubsection{Araştırmaya Katılanların Sektördeki İş tecrübesi Sonuçları}

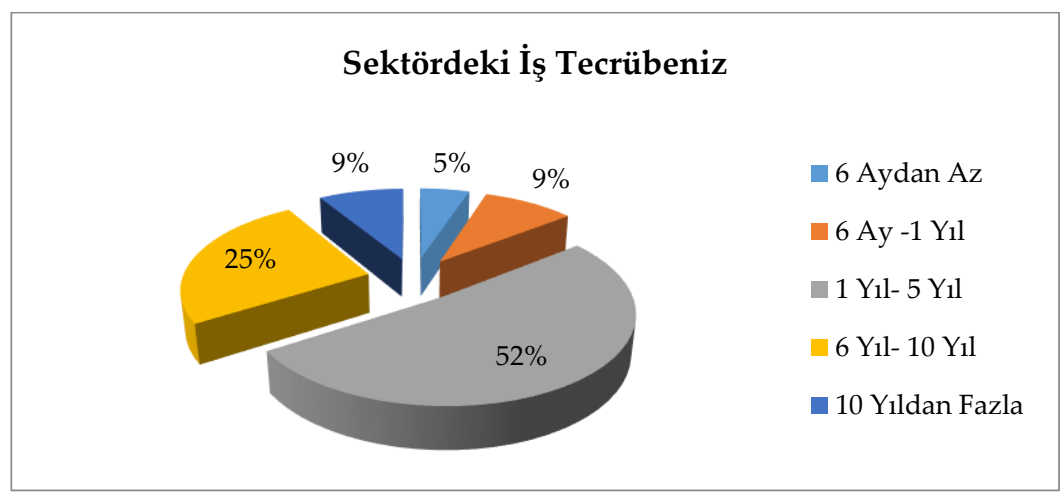

Araştırmaya katılan turizm çalışanlarının $7^{\prime}$ si 6 aydan az (\%5), 13' ü 6 ay -1 yıl (\%9), 71' i 1 yıl- 5 yil (\%52), 35' i 6 yil- 10 yıl (\%25), 12' si 10 yıldan fazla iş tecrübesine sahiptir (\%9).

\subsubsection{Araştırmaya Katılanların Medeni Durum Sonuçları}

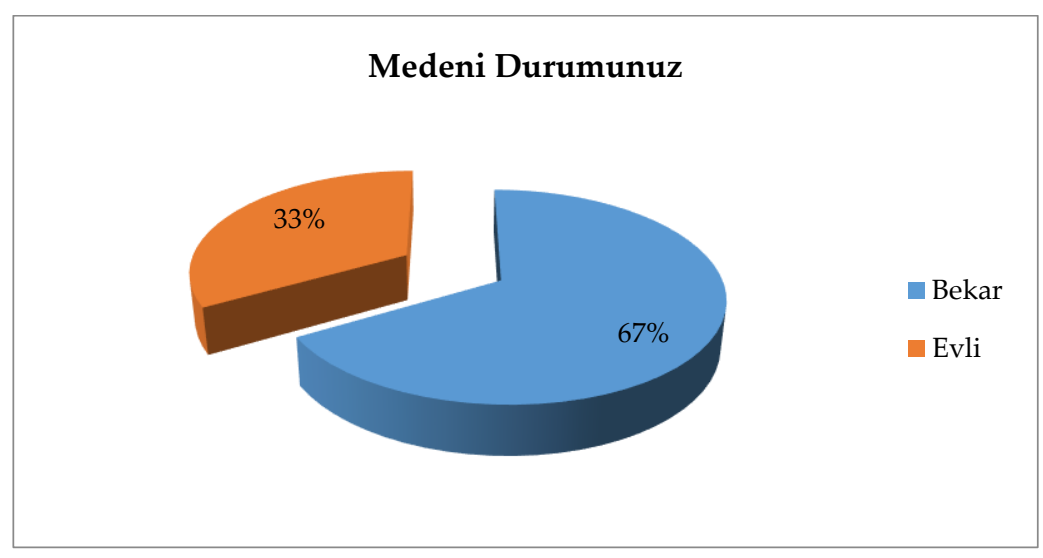


Araştırmaya katılan turizm çalışanlarının 92' si bekar (\%67), 46’ sı evli medeni durumuna sahiptir (\%33).

\section{Hipotezlerin Değerlendirilmesi}

Soruların çatışma yönetim stili yaklaşımlara göre dağılımı aşağıdaki gibidir.

$\checkmark$ Bütünleştirme: 1, 3, 12, 13, 16

$\checkmark$ Uyma- Ödün Verme: $2,8,10,14$

$\checkmark$ Hükmetme: 6, 7, 11

$\checkmark$ Kaçınma: 4, 15

$\checkmark$ Uzlaşma: 5, 9

Buna göre çalışmanın hipotezleri aşağıda şöyle sıralanmıştır.

“H1: Bütünleştiren yönetim stili, lider- ̈̈ye etkileşimi niteliğini pozitif yönde etkilemektedir." H-1 test edilmek istendiğinde bütünleştirici yaklaşıma ait yargılara göz atmak gerekmektedir.

Tablo 1. Kabul edilebilir bir çözüm bulabilmek için sorunu çalışanlarıla birlikte gözden geçirir.

\begin{tabular}{llc}
\hline Bütünleştirme & Yüzde & Kümülatif Yüzde \\
\hline Kesinlikle Katılmıyorum & 2,2 & 2,2 \\
Katılmıyorum & 9,4 & 11,6 \\
Kararsız & 16,7 & 28,3 \\
Katıllyorum & 53,6 & 81,9 \\
Kesinlikle Katıllyorum & 18,1 & 100,0 \\
Toplam & $\mathbf{1 0 0 , 0}$ & \\
\hline
\end{tabular}

Tablo 2. Çalışanlarıyla ortak bir çözüm bulmak için fikirlerini çalı̧̧anlarının fikirleriyle birleştirir.

\begin{tabular}{llc}
\hline Bütünleştirme & Yüzde & Kümülatif Yüzde \\
\hline Kesinlikle Katılmıyorum & 2,2 & 2,2 \\
Katılmıyorum & 13,0 & 15,2 \\
Kararsız & 15,9 & 31,2 \\
Katıllyorum & 46,4 & 77,5 \\
Kesinlikle Katıllyorum & 22,5 & 100,0 \\
Toplam & $\mathbf{1 0 0 , 0}$ & \\
\hline
\end{tabular}


Tablo 3. Bir sorunun en iyi şekilde çözümlenmesi için bütün kaygılarını açıkça ortaya koymaya çalışır.

\begin{tabular}{llc}
\hline Bütünleştirme & Yüzde & Kümülatif Yüzde \\
\hline Kesinlikle Katılmıorum & 0,7 & 0,7 \\
Katılmiyorum & 12,3 & 13,0 \\
Kararsız & 21,7 & 34,8 \\
Katılıyorum & 48,6 & 83,3 \\
Kesinlikle Katılıyorum & 16,7 & 100,0 \\
Toplam & $\mathbf{1 0 0 , 0}$ & \\
\hline
\end{tabular}

Tablo 4. Kabul edilebilir sorunların çözülebilmesi için çalışanlarıyla işbirliği yapar.

\begin{tabular}{lll}
\hline Bütünleştirme & Yüzde & Kümülatif Yüzde \\
\hline Kesinlikle Katılmıyorum & 2,9 & 2,9 \\
Katılmıyorum & 10,9 & 13,8 \\
Kararsız & 17,4 & 31,2 \\
Katıliyorum & 47,8 & 79,0 \\
Kesinlikle Katıliyorum & 21,0 & 100,0 \\
Total & $\mathbf{1 0 0 , 0}$ & \\
\hline
\end{tabular}

Tablo 5. Sorunların tam ve doğru olarak anlaşılması için çalışanlarıla birlikte çalişmaya gayret eder.

\begin{tabular}{lll}
\hline Bütünleştirme & Yüzde & Kümülatif Yüzde \\
\hline Kesinlikle Katılmiyorum & 2,2 & 2,2 \\
Katılmiyorum & 9,4 & 11,6 \\
Kararsız & 18,8 & 30,4 \\
Katılıyorum & 48,6 & 79,0 \\
Kesinlikle Katılıyorum & 21,0 & 100,0 \\
Total & $\mathbf{1 0 0 , 0}$ & \\
\hline
\end{tabular}

Lider-üye etkileşiminin bütünsel yönetim yaklaşımı ile pozitif yönlü bir ilişki olduğuna dair bulgular ilgili yönetim stiline ait yargılarına verilen cevaplara bakıldığında görülmektedir. Ankete katılan bireyler yüksek oranda yargılara "Kesinlikle katıliyorum" ve "Katıliyorum" ifadeleriyle cevaplayarak lider-üye etkileşiminin bütünsel yaklaşım ile çözüm odaklı bir şekilde yönetilebileceği şeklinde yorumlamışlardır. “H2: Uyma- Ödün 
Verme yönetim stili, lider- üye etkileşimi niteliğini pozitif ve anlaml yönde etkilemektedir.". H2 test etmek gerekirse, ilgili yargilara verilen cevaplara baktığımızda:

Tablo 6: Genellikle çalışanların ihtiyaçlarını karşılar.

\begin{tabular}{lll}
\hline Uyma-Ödün Verme & Yüzde & Kümülatif Yüzde \\
\hline Kesinlikle Katılmiyorum & 2,2 & 2,2 \\
Katılmiyorum & 19,6 & 21,7 \\
Kararsız & 15,9 & 37,7 \\
Katıllyorum & 46,4 & 84,1 \\
Kesinlikle Katıllyorum & 15,9 & 100,0 \\
Total & $\mathbf{1 0 0 , 0}$ & \\
\hline
\end{tabular}

Tablo 7. Çalışanlara genellikle taviz verir.

\begin{tabular}{lll}
\hline Uyma-Ödün Verme & Yüzde & Kümülatif Yüzde \\
\hline Kesinlikle Katılmıorum & 16,7 & 16,7 \\
Katılmiyorum & 40,6 & 57,2 \\
Kararsız & 23,2 & 80,4 \\
Katılıyorum & 15,2 & 95,7 \\
Kesinlikle Katıllyorum & 4,3 & 100,0 \\
Total & $\mathbf{1 0 0 , 0}$ & \\
\hline
\end{tabular}

Tablo 8. Genellikle çalışanların önerileri doğrultusunda hareket eder.

\begin{tabular}{lll}
\hline Uyma-Ödün Verme & Yüzde & Kümülatif Yüzde \\
\hline Kesinlikle Katılmıyorum & 13,0 & 13,0 \\
Katılmiyorum & 32,6 & 45,7 \\
Kararsız & 26,1 & 71,7 \\
Katıliyorum & 26,1 & 97,8 \\
Kesinlikle Katıllyorum & 2,2 & 100,0 \\
Total & $\mathbf{1 0 0 , 0}$ & \\
\hline
\end{tabular}

Tablo 9 Çalı̧̧anlarn beklentilerini karşılamaya çalışır.

\begin{tabular}{lll}
\hline Uyma-Ödün Verme & Yüzde & Kümülatif Yüzde \\
\hline Kesinlikle Katılmıyorum & 2,2 & 2,2 \\
Katılmiyorum & 18,1 & 20,3 \\
Kararsız & 17,4 & 37,7 \\
Katılıorum & 46,4 & 84,1 \\
Kesinlikle Katıllyorum & 15,9 & 100,0 \\
Total & $\mathbf{1 0 0 , 0}$ & \\
\hline
\end{tabular}


Verilen cevaplar dikkate alındığında; uyma-ödün verme yönetim biçimi ile kurulan liderlik üye etkileşimi çalışanlar nezninde pozitif ve çözüm odaklı yönetim anlayışı şeklinde kabul görmekte ve yaklaşımın pozitif yönlü cevap bulduğu görülmektedir.

"H3: Hükmetme yönetim stili, lider- üye etkileşimi niteliğini negatif ve olumsuz yönde etkilemektedir." Üçüncü hipotezi incelemek istediğimizde:

Tablo 10. Fikirlerini kabul ettirmek için çalışanları üzerinde etki gücünü kullanır

\begin{tabular}{lll}
\hline Hükmetme & Yüzde & Kümülatif Yüzde \\
\hline Kesinlikle Katılmiyorum & 8,7 & 8,7 \\
Katılmiyorum & 23,2 & 31,9 \\
Kararsız & 16,7 & 48,6 \\
Katıliyorum & 37,7 & 86,2 \\
Kesinlikle Katıliyorum & 13,8 & 100,0 \\
Total & $\mathbf{1 0 0 , 0}$ & \\
\hline
\end{tabular}

Tablo 11. Bir kararı kendi lehine çevirmek için otoritesini kullanır

\begin{tabular}{lll}
\hline Hükmetme & Yüzde & Kümülatif Yüzde \\
\hline Kesinlikle Katılmiyorum & 8,7 & 8,7 \\
Katılmiyorum & 29,7 & 38,4 \\
Kararsiz & 20,3 & 58,7 \\
Katıliyorum & 23,9 & 82,6 \\
Kesinlikle Katıliyorum & 17,4 & 100,0 \\
Total & $\mathbf{1 0 0 , 0}$ & \\
\hline
\end{tabular}

Tablo 12. Sorunları kendi bakış açısından değerlendirmek konusunda katıdır

\begin{tabular}{lll}
\hline Hükmetme & Yüzde & Kümülatif Yüzde \\
\hline Kesinlikle Katılmiyorum & 6,5 & 6,5 \\
Katılmiyorum & 30,4 & 37,0 \\
Kararsiz & 22,5 & 59,4 \\
Katıliyorum & 26,8 & 86,2 \\
Kesinlikle Katıliyorum & 13,8 & 100,0 \\
Total & $\mathbf{1 0 0 , 0}$ & \\
\hline
\end{tabular}

Ankete katılan katılımcılar, lider-üye etkileşimi konusunda hükmetme odaklı yönetsel yaklaşım odağında yöneltilen ifadelere verdikleri cevapların yoğunluğu dikkate alındığında olumsuz bir algı olduğu görülmektedir. Bu durumda da hipotezin gerçekliği konusunda çıkarımda bulunmamızı sağlamaktadır. 
Kaçınma yönetim stiline ait hipotezi incelemek istersek; "H4: Kaçınma yönetim stili, lider- ̈̈ye etkileşimi niteliğini negatif ve olumsuz yönde etkilemektedi". Bu yönetim stilene ait yargılara verilen cevaplara bakıldığında;

Tablo 13. Çalışanlarıla olan farklılıklarını açıkça tartışmaktan çoğu zaman kaçınır

\begin{tabular}{lll}
\hline Kaçınma & Yüzde & Kümülatif Yüzde \\
\hline Kesinlikle Katılmıyorum & 10,1 & 10,1 \\
Katılmıyorum & 25,4 & 35,5 \\
Kararsız & 23,9 & 59,4 \\
Katılıyorum & 31,2 & 90,6 \\
Kesinlikle Katılıyorum & 9,4 & 100,0 \\
Total & $\mathbf{1 0 0 , 0}$ & \\
\hline
\end{tabular}

Tablo 14. Çalışanların duygularını incitmemek için onlarla olan uyuşmazlı̆̆ını saklar.

\begin{tabular}{lll}
\hline Kaçınma & Yüzde & Kümülatif Yüzde \\
\hline Kesinlikle Katılmıorum & 8,0 & 8,0 \\
Katılmiyorum & 21,0 & 29,0 \\
Kararsız & 26,1 & 55,1 \\
Katılıyorum & 31,9 & 87,0 \\
Kesinlikle Katılıyorum & 13,0 & 100,0 \\
Total & $\mathbf{1 0 0 , 0}$ & \\
\hline
\end{tabular}

Kaçınma odaklı yönetim stiline ait cevaplara dikkate alındığında, katılımcıların büyük bir yoğunluğu yönetim stili olarak kaçınarak sorunları çözmeye çalışan yöneticilere olumsuz gözle bakıldığını düşündükleri ifade edilebilecektir. Bu bağlamda $\mathrm{H} 4$ hipotezi de doğru olarak kanitlanacaktır.

Son yönetim biçimi olarak uzlaşmacı lider üye etkileşimine ait hipotezi test etmek istersek; "H5: Uzlaşma yönetim stili, lider- üye etkileşimi niteliğini pozitif ve anlaml yönde etkilemektedir"

Tablo 15. İçinden çıkılmaz durumları çözmek için orta bir yol bulmaya çalışır.

\begin{tabular}{lll}
\hline Uzlaşma & Yüzde & Kümülatif Yüzde \\
\hline Kesinlikle Katılmıorum & 3,6 & 3,6 \\
Katılmıyorum & 8,7 & 12,3 \\
Kararsız & 15,2 & 27,5 \\
Katıliyorum & 49,3 & 76,8 \\
Kesinlikle Katılıyorum & 23,2 & 100,0 \\
Total & $\mathbf{1 0 0 , 0}$ & \\
\hline
\end{tabular}


Tablo 16. Çalışanlarıyla uzlaşmaya varmak için karşılıklı görüşmeler yapar.

\begin{tabular}{lll}
\hline Uzlaşma & Yüzde & Kümülatif Yüzde \\
\hline Kesinlikle Katılmiyorum & 1,4 & 1,4 \\
Katılmiyorum & 9,4 & 10,9 \\
Kararsiz & 15,9 & 26,8 \\
Katılıyorum & 58,7 & 85,5 \\
Kesinlikle Katılıyorum & 14,5 & 100,0 \\
Total & $\mathbf{1 0 0 , 0}$ & \\
\hline
\end{tabular}

Uzlaşma odaklı yönetim stili ile lider-üye etkileşim odaklı yargılara verilen cevaplar dikkate alındığında; çalışanların uzlaşmacı yöneticilere karşı pozitif yaklaşımları olduklarına yönelik cevapları Tablo-15 ve Tablo16 ' da görülmektedir. Burada çalışanların yönetime katılımcı ve ılıman yöneticilere karşı daha çözüm odaklı ve çalışmayı benimseyen bir yaklaşımı olduğu yorumu yapılabilecektir.

\section{Değerlendirme ve Sonuç}

Çalışma, İstanbul' da turizm sektöründe ki yöneticilerin çatışma yönetim stillerinin, lider-üye etkileşimi üstündeki tesirini görebilmek amacıyla yapılmıştır. Yapılan çalışmaya göre, başvurulan çatışma yönetim stillerinin lider-üye etkileşimi üstünde aktif rol oynadığı söylenebilir.

Artan rekabet ortamında, değişim gösteren içsel ve dışsal tüm etkenler göz önüne alındığından örgütler için etkililik ve verimlilik önem arz etmektedir. Diğerlerinden fark yaratan bir performansa sahip olmak isteyen örgütler elindeki ilk kaynak olarak insan kaynağına yönelip var olan potansiyelinin nasıl ortaya konabileceğini, nasıl artırabileceğinin sorularını sormaktadır. Bu noktada tabi ki örgüt yönetiminin eli olan yöneticilere büyük oranda iş düşmekte olup onların çalışan üzerindeki etkileri sorgulanmaktadır. Örgütün lideri olarak nitelendireceğimiz bu kişiler alt kademe de bulunan liderin üyeleri durumundaki iş görenlerle ilişkilerinde hangi yönde davranırlarsa performansı artacak taraflar arasındaki ilişki gündemde olmuştur. Bu bağlamda yüksek verimlilik fark yaratan bir performans için yönetimin eğildikleri başlıca konu olarak lider üye arasındaki ilişkinin niteliği olacaktır. Çünkü niteliği yüksek lider üye etkileşimi iş tatmini, iş performansını artıracak yaratıcılığı ortaya koymalarında fayda sağlayacaklarıdır. Bu noktada her üye ile nitelik bakımından yüksek 
ilişkiler kurulamayabilir. Bunu çözmenin yolu liderin tarafa yaklaşımları etkili olacaktır.

Yaşamın her alanında olduğu gibi örgütler içerisinde de çatışmanın varlığından söz etmemek imkansız olacaktır. Yapılan araştırmalar çatışmaların iyi yönetildiğinde işlevsel olabileceğini göstermiştir. Bu anlamda çatışmanın lider tarafında doğru çatışma yönetim stilinin belirlenmesi üye tarafından algılanan kısımda olumlu ve pozitif görüldüğü anlaşılmıştir.

Yapılan bu çalışmanın 1şığında lider üye ilişkilerinde çatışma yönetim stilinin etkisi olduğu inkar edilemez. Ancak bazı ayrıntılar da unutmamak gerekir ki taraflar arasındaki ilişkininin niteliğini belirleyen karakteristik bazı özellikler, örgütün imaj ve yapısı, kültürel kodlamalar gibi değişkenlerinde etkisinden söz etmek mümkün olacaktır.

Çalışmanın İstanbul' da turizm sektöründe yapıldığını göz önüne ald1ğımızda kesin değişmez sonuçların elde edileceğini söylemek mümkün değildir. Bu anlamada farklı çerçevede yapılan araştırmalarında konuya yaklaşımın belirlenmesinde kolaylık sağlayabileceği söylenebilir. 


\title{
EXTENDED ABSTRACT
}

\section{Relationship Between Leader Member Interaction and Conflict Management Style: A Field Research}

\author{
Mehmet Güler \\ İstanbul University
}

Traditionally defined leadership approach; to gather a certain group of people around specific goals and having the necessary qualifications, skills and experience to activate them in order to achieve these objectives.

Collaboration between people is necessary for the realization of organizational goals and for the organization to be successful and effective. Since the creation of human beings, there is a need for leaders who will provide this cooperation and work the audience with pleasure. However, since the foundation of organizational activities is based on the human element and communication and interaction are inevitable wherever there is human, it is very important to understand how inter-human relations begin and continue in social life. Because this communication and interaction process affects employees' perceptions, attitudes and behaviors that will affect organizational productivity. In order for organizations to survive in a competitive environment, productivity, as well as adaptation to change, development and innovation, must be maximized. Therefore, managers are constantly in search of increasing the productivity of employees.

The most important point where the leader member interaction theory differs from other leadership approaches is that it focuses not only on the leader but also on the quality of the relationship and interaction between the leader and its members. Under the LUE theory, members tend to exert a high level of effort to relate to their leaders with the desire to engage in high-quality interaction, while leaders tend to reward and respond to them by providing more social support and organizational resources.

Conflict is defined as an interactive process that emerges between social entities as a result of disputes and conflicts. the presence of people 
with value judgment, worldview and goals makes the conflict inevitable. Conflicts in organizations, if not managed well, will negatively affect the motivation of the members of the organization and thus decrease their productivity.

One of the most important factors that increase an employee's organizational contribution is the leader. If the level of interaction between the leader and the follower is positively high, he becomes ready to do what is necessary for the member organization and leader, and even more. The quality of the relationship between the manager and the manager is decisive in order to be able to use the human being, which is the most important resource in the organizational level, to reveal the potential within it, to make him / her connected to his / her work and his / her organization and to make him / her more motivated. There are studies suggesting that increased interaction between leaders and followers in an organization increases organizational productivity, and leaders can influence their relationship with their followers by applying certain conflict management styles.

Like the conflict management relationship between a leader and a follower, the dual relationship between a leader and a follower is processcentered. Leader-member relationship is the key concept in the leadership process. Conflict management and bilateral relations between leaders and followers are issues that pose problems for contemporary leadership. Leaders influence their followers and hence have an impact on all variables that affect conflict within a group The importance of understanding relationships between managers and employees in organizations, well diagnosing existing problems and finding the right interventions and solutions to problems is increasingly felt when the literature is examined. While there is no national study examining conflict management together, Green (2007) conducted the only international study. Based on this gap in the literature, the quality of the leader-member interaction of the participants and the conflict management style frequently used by the leaders were determined and whether there was a statistically significant relationship between the determined leader-member interaction and the conflict management style was investigated. 
In this study, the quality of leader-member interaction and the conflict management style commonly used by leaders and whether there is a statistically significant relationship between leader-member interaction and leaders often used conflict management style were obtained. The quality of leader-member interaction was quite high. high. Accordingly, although there is a quality interaction between the leaders and their members, this interaction shows that both sides have an effective and productive relationship with each other.

Conflict management style, which is often used by leaders in managing conflict within the organization, was found to be problem solving style. According to this; It is possible to conclude that the leaders act responsibly and relevant to their members, openly share their knowledge with them, and seek to find alternative ways to solve their problems and strive for creative solutions. In addition, in many studies, it has been determined that problem solving style is the most appropriate way to manage conflict. A statistically significant and positive correlation was found between the leader-member interaction and the conflict management style frequently used by the leaders. From here; It can be concluded that leaders take into account their interaction with members in determining the conflict management style they frequently use.

To summarize the results; Managers should not aim to end the conflicts within the organization completely, should eliminate the harmful aspects of the conflict as much as possible, but should also take into consideration the aspects of the conflict that will contribute to organizational development, and effectively manage it, and aim to bring it to the optimum yield for both the organization and employees. In addition to the results obtained, the inclusion of other variables in the analysis and further investigation will increase the benefit of this study. The most important issue that should not be forgotten is that manager-manager, manager-subordinate and subordinate-subordinate harmony must be ensured within an organization. In order to achieve this, the values, ideas and suggestions of all working groups should participate in the process in the most effective and efficient manner 


\section{Kaynakça / References}

Alkan, Z. (2016). Liderlik tarzlarının örgütsel sessizlik ilişkisinde kariyer memnuniyetinin rolü. Yayımlanmamış Yüksek Lisans Tezi, Ondokuz Mayıs Üniversitesi, Sosyal Bilimler Enstitüsü, Samsun.

Altay, M. (2011). Çatışma yönetim tarzlarmın lider-üye etkileşimi üzerine etkisi: Yazılım sektöründe bir araştırma. Yayımlanmamış Yüksek Lisans Tezi, Kara Harp Okulu, Ankara.

Bayık, M. E.(2016). Askeri liderlerin çatışma yönetiminde üçüncü taraf müdahale stratejileri ve sonuçları. Yayımlanmamış Yüksek Lisans Tezi, Kara Harp Okulu, Ankara.

Bucak, F. (2010). Ankara'da iki farklı hastanede görev yapan yönetici hemşirelerin liderlik yaklaşımlarının ve çatışma yönetimi stratejilerinin astları tarafindan algılanma durumları. Yayımlanmamış Yüksek Lisans Tezi, Gazi Üniversitesi Sağlık Bilimleri Enstitüsü, Ankara.

Dağlı, B.,vd. (2014). Liderin çatışma yönetiminde arabuluculuk rolü. Research Journal of Business and Management, 1(2), 87-102.

Demiröz, K. C. (2015). Genç çalışanların öz liderlik algılarıyla yöneticilerinin çatışma yönetimi tarzı arasındaki ilişkinin incelenmesi. Yayımlanmamış Doktora Tezi, Okan Üniversitesi, Sosyal Bilimler Enstitüsü, İstanbul.

Dönmezer, S. (1999). Toplumbilim. İstanbul: Beta Yayınları.

Ergun, T. ve Polatoğlu, A.(1988). Kamu yönetimine giriş. Ankara: Todaie.

Findıkl1, Afacan, M. (2012). İş değerleri perspektifinde yönetici çalışan uyumu ve iş tatmini ile lider -üye etkileşimi üzerine türk sağllk sektöründe bir araştırma. Yayımlanmamış Doktora Tezi, İstanbul üniversitesi Sosyal Bilimler Enstitütüsü, İstanbul.

Karcığulları F. ve Alioğulları Z. (2012). Çatışmanın nedenleri ve çatışma yönetim tarzları ilişkisi. Atatürk Üniversitesi İktisadi ve İdari Bilimler Dergisi, 26(3-4). 215-237.

Kirişçi, A. (2010). Öğretmenlerin kültürel değerleri ve çatışma yaklaşımları. Yayımlanmamış Yüksek Lisans Tezi, Yıldız Teknik Üniversitesi, Eğitim Bilimleri Enstitüsü, İstanbul. 
Nebioğlu, O. (2011). Seyahat acentesi yöneticilerin liderlik tarzları ve çatışma yönetimi ilişkisi: Alanya bölgesi A grubu seyahat acenteleri uygulaması. Yayımlanmamış Yüksek Lisans Tezi, Gazi Üniversitesi Eğitim Bilimleri Enstitüsü, Ankara.

Şişman, M. (1997). Geleceğin liderlerinin yetiştirilmesi ve eğitimde liderlik 21. Yüzyılda Liderlik Sempozyumu, 5-6 Haziran, İstanbul.

Tabak, A. (2005). Lider ve takipçileri. Ankara:Asil Yayın Dağıtım.

Turan, M.(2014). Acil yardım, kurtarma ve müdahale çalışanlarının liderlik stilleri ile çatışma yönetim stratejilerinin ilişkisi üzerine bir çalışma: Erzurum ili örneği. Yayımlanmamış Yüksek Lisans Tezi, Gümüşhane Üniversitesi Sosyal Bilimler Enstitüsü, Gümüşhane.

Zel, U. (2006). Kişilik ve liderlik (2.Bsm). Ankara: Nobel Yayın Dağıtım.

\section{Kaynakça Bilgisi / Citation Information}

Güler, M. (2019). Lider üye etkileşimi ve çatışma yönetim stili ilişkisi: Bir alan araştırması. OPUS-Uluslararası Toplum Araştırmaları Dergisi, 11(18), 1136-1166. DOI: 10.26466/opus.529924 